EESTI NSV TEADUSTE AKADEEMIA TOIMETISED. $X$ KOIDE

FOOSIKALIS-MATEMAATILISTE JA TEHNILISTE TEADUSTE SEERIA, 1961, NR. 1

ИЗВЕСТИЯ АКАДЕМИИ НАУК ЭСТОНСКОИ ССР. ТОМ Х СЕРИЯ ФИЗИКО-МАТЕМАТИЧЕСКИХ И ТЕХНИЧЕСКИХ НАУК. 1961, № 1

\title{
О ХИМИЗМЕ ПРОЦЕССА СИНТЕЗА АЛКИЛСУЛЬФАТОВ НА БАЗЕ ОЛЕФИНОВ СЛАНЦЕВОЙ СМОЛЫ
}

\author{
и. Б. КУДРЯВЦЕВ, \\ кандидат технических наук
}

В настоящее время в общем производстве синтетических моющих средсть значительный удельный вес занимают моющие средства, изготовленные на основе вторичных моноалкилсульфатов натрия. Последние получаются путем сернокислотной обработки олефиновых углеводородов, образующихся в результате крекинга нефтяных или синтетических парафинов.

Такие моющие вещества в виде 40 - или $20 \%$-ных водных растворов, известных под фирменным наименованием «Типол», получили за рубежом широкое распространение в качестве жидкого моющего и смачивающего средства.

Процесс синтеза моноалкилсульфоэфиров заключается в присоединении серной кислоты к олефиновым углеводородам по месту двойной связи:

$$
\begin{aligned}
R-\mathrm{CH}=\mathrm{CH}_{2}+\mathrm{HQ}-\mathrm{SO}_{2}-\mathrm{OH} \rightarrow R- & \mathrm{CH}-\mathrm{CH}_{3} \\
& \mathrm{O}-\mathrm{SO}_{2}-\mathrm{OH}
\end{aligned}
$$

При этом возможно протекание ряда побочных реакций полимеризации, окисления углеводородов, образования диалкилсульфатов, ведущих не только к снижению выхода целевого продукта, но даже к ухудшению его качества. Следует отметить, что удельный вес таких паразитических реакций колеблется в широких пределах в зависимости от условий ведения процесса, а также, конечно, и от характера исходного сырья. Естественно, что наличие в сланцевой смоле значительных количеств углеподородов других классов, а также кислородных соединений еще больше увеличивает зозможность различных превращений. В связи с этим изучение хнмизма процесса сульфагирования олефинов сланцевой смолы является необходимым разделом проблемы спнтеза моющих веществ.

\section{Методика исследования}

Наиболее эффективным методом исследования химизма рассматриваемого процесса явилось хроматографическое разделение исходного сырья на основные химнческие группы, которые затем порознь были подвергнуты действию концентрированной серной кислоты, с последующим анализом полученных сульфопронзводных и несульфированного сырья. Хроматографическое разделение осуществлялось методом селективного вымывания при помощи различных растворителей адсорбированного на актнвнрсванном силикагеле сырья [1-4]. Переход от одной химической группы к другой определялся по трем величинам: показателю преломления при $20^{\circ}$, величине бромного числа, определявшегося амперометрическим титрованием бромид-броматным раствором [5], и рассчитанному интерцепту рефракции. Определение содержания гидроксильной группы проводилось методом ацетилирования уксусным ангидридом в растворе пиридина []. Содержание карбонильной группы определялось методом оксимирования солянокислым гидроксиламином в присутствии едкой щелочи [7]. Количество активного вещества в сульфопродукте и его молекулярный вес устанавливались при помощи солянокислого $n$-толуидина [8,9], а количество сульфоэфиров в активном веществе методом гидролитического разложения в кислой среде с последуюшим определением содержания гидроксильной группы в продуктах гидролиза.

4 ENSV TA Toimetised T-1 61 


\section{Превращение основных химических групп сланцевой смолы под действием серной кислоты}

Исходным сырьем для исследования процесса сульфатирования служила обесфеноленная фракция $250-350^{\circ}$ смолы, получаемой на установке термической переработки сланца с твердым теплоносителем [ $\left.{ }^{11}\right]$.

Молекулярный вес фракции соответствовал среднему содержанию 17 атомов углерода в молекуле, что примерно равняется среднему числу атомов углерода в гидрофобной части молекулы жирового мыла.

Процесс сульфатирования осуществлялся периодически при температуре $10-15^{\circ}$ и продолжительности контакта с серной кислотой около $1 \frac{1}{2}$ часов. Оптимальный избыток серной кислоты, определенный для олефинов данного молекулярного веса, соответствовал молярному отношению кислота: олефины, равному $3: 1$. В результате сульфатирования и последующего отстаивания образуется два слоя.

Верхний, так называемый масляный слой, обладающий умеренной кислотностью, состоит в основном из несульфированного сырья и содержит продукты полимеризации олефинов, диалкилсульфаты и т. п. Кроме того, после нейтрализации из масляного слоя экстрагируется значительное количество сульфопродукта.

Нижний, кислотный слой, представляет собой совокупность целого ряда сложных соединений и большей части свободной серной кислоты. Здесь же растворены образовавшиеся алкилсульфоэфиры.

Нейтрализация обоих слоев проводится параллельно $20 \%$-ным водным раствором едкого натра, причем для масляного слоя она осуществляется из такого расчета, чтобы в конечном итоге система имела некоторый избыток щелочи, необходимый для последующего гидролиза диалкилсульфатов.

Процессом нейтрализации по существу и заканчивается синтез сульфопродукта.

Далее следуют щелочной гидролиз диалкилсульфатов (в случае масляного слоя) и операции выделения сульфопродукта из общей реакщионной смеси при помощи водного раствора изопропилового спирта, рафинации и упаривания водного раствора сульфопродукта до требуемой концентрации [12].

Таким образом получают два вида сульфопродукта: а) из масляного слоя и б) из гудрона, суммарный выход которых достигает $20-25 \%$ от исходной фракции. Сульфопродукт, полученный из масляного слоя, обладает значительно лучшими качествами по цвету, запаху и .поверхностно-активным свойствам, чем второй.

Изучение процесса сульфоэтерификации фракции $250-350^{\circ}$ показало, что большинство основных химических компонентов подвергается в присутствии серной кислоты существенным превращениям.

В табл. 1 сопоставлены результаты хроматографического разделения исходной фракции $250-350^{\circ}$ и нейтральной части масляного слоя этой же фракции, полученного в результате процесса сульфоэтерификации.

Как и следовало ожидать, насыщенные углеводороды не претерпевают каких-либо существенных изменений и их количество остается более или менее постоянным $(3,9$ и $4,3 \%)$. Олефиновые углеводороды, несмотря на большой избыток применяемой серной кислоты, частично остаются в составе отработанной фракции. Общее содержание олефи- 
нов уменьшается с 15,3 до 5,0\%. Последние представлены в основном моноолефинами и не содержат сернистых соединений, присутствие которых в соответствующей области исходной фракции было сопряжено с наличием диолефиновых углеводородов.

Таблица I

Изменение группового химического состава обесфеноленной фракции $250-350^{\circ}$ в результате обработки серной кислотой

\begin{tabular}{|c|c|c|c|}
\hline \multirow[b]{2}{*}{ Групповой химический компонент } & \multirow{2}{*}{$\begin{array}{c}\text { Содержание } \\
\text { в исходной } \\
\text { фракции, } \\
\text { вес. } \%\end{array}$} & \multicolumn{2}{|c|}{$\begin{array}{l}\text { Содержание в отра- } \\
\text { ботанной фракции }\end{array}$} \\
\hline & & Bec. $\%$ & $\begin{array}{c}\text { в пересчете } \\
\text { на исходную } \\
\text { фракцию, } \\
\text { вес. } \%\end{array}$ \\
\hline $\begin{array}{l}\text { Парафиновые и нафтеновые углеводо- } \\
\text { роды } \\
\text { Олефиновые углеводороды } \\
\text { Ароматические углеводороды } \\
\text { Промежуточные ароматические соеди- } \\
\text { нения } \\
\text { Нейтральные кислородные соединения } \\
\text { Потери }\end{array}$ & $\begin{array}{r}3,9 \\
15,3 \\
28,7\end{array}$ & $\begin{array}{l}10,5 \\
12,1 \\
21,4\end{array}$ & $\begin{array}{l}4,3 \\
5,0 \\
8,8\end{array}$ \\
\hline
\end{tabular}

Более четкая картина поведения олефиновых углеводородов была получена в результате сульфоэтерификации парафин-олефин-нафтеновых углеводородов, выделенных из фракции 250-350 графического разделения на силикагеле. Содержание олефинов в концентрате указанных углеводородов, средний молекулярный вес которых равнялся 232 , составляло около $80 \%$.

Несульфированная часть масляного и кислотного слоев, образующихся в результате сернокислотной обработки, повторно разделялась при помощи хроматографирования. Результаты анализов приведены в табл. 2.

Из табл. 2 видно, что и в данном случае значительная часть олефинов остается в отработанном сырье (см. величины бромных чисел отдельных хроматографических фракций масляного слоя). При этом следует полагать, что подавляющее большинство присутствующих в масляном слое олефинов не вступало во взаимодействие с серной кислотой. Еісли средний молекулярный вес исходных олефинов равнялся $230-232$, то у остаточных олефинов масляного слоя он составляет 245-259.

С другой стороны, результаты хроматографического разделення масляного остатка кислотного слоя и последующего всестороннего анализа его углеводородной части показывают, что последняя представляет собой смесь продуктов, полученных в результате весьма глубоких превращений олефиновых углеводородов. Молекулярный вес соответствующих хроматографических фракций равняется в среднем 320 , а его максимальное значение достигает 375 . Кроме того, масляный остаток кислотного слоя содержит значительное количество кислородных и сернистых соединений.

Кислородные соединения, как показывает кислородный баланс соответствующих хроматографических фракций, содержат в основном карбонильные и гидроксильные группы, количество которых колеблется соответственно в пределах $4-12$ и $0,7-5,0 \%$.

Хроматографические фракции № 7 масляного слоя и № 5 кислот- 
ного слоя содержат в среднем $11-12 \%$ карбонильных групп. Такую величину надо признать высокой, так как при наличии одной карбонильной группы в молекуле, имеющей молекулярный вес 320 или 386, содержание карбонильной группы будет составлять соответственно 8,8 или $7,5 \%$. Образование нескольких карбонильных групп в молекуле следует считать возможным при сульфатировании диолефиновых углеводородов, весьма склонных, по всей вероятности, к окислению при данных условиях.

Таким образом, наряду с реакцией полимеризации известное место занимает реакция окисления непредельных соединений. Продукты такого глубокого превращения олефинов концентрируются главным образом в кислотном слое.

На основании приведенных выше данных хроматографического разделения и результатов анализа получаемого сульфопродукта на содержание алкилсульфоэфира и определения его молекулярного веса удалось получить представление о поведении олефинов сланцевой смолы в процессе их сульфатирования 98\%-ной серной кислотой. Результаты исследования сведены в материальном балансе, который представлен в табл. 3.

Таблица 3

Материальный баланс процесса сульфатирования по олефиновым углеводородам фракции $250-350^{\circ}$ сланцевой смолы

\begin{tabular}{|c|c|c|c|c|c|}
\hline \multicolumn{3}{|l|}{$\mathrm{Pacxoд}$} & \multicolumn{3}{|l|}{ Приход } \\
\hline \multirow[b]{2}{*}{ Статьи расхода } & \multicolumn{2}{|c|}{ Bec. $\%$} & \multirow[b]{2}{*}{ Статьи прихода } & \multicolumn{2}{|c|}{ Bec. $\%$} \\
\hline & 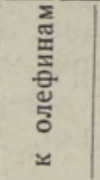 & 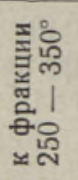 & & 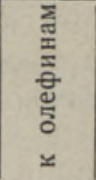 & 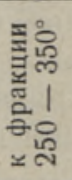 \\
\hline $\begin{array}{l}\text { Олефиновые углеводороды } \\
\text { фракции } 250-350^{\circ}\end{array}$ & 100,0 & 15,3 & $\begin{array}{l}\text { Олефины в моносульфо- } \\
\text { эфирах: } \\
\text { масляного слоя } \\
\text { кислотного } \\
\text { Остаточные олефины } \\
\text { Полимерные } \\
\text { Олефины в кислородных и } \\
\text { сернистых соединениях } \\
\text { Потери }\end{array}$ & $\begin{array}{r}10,8 \\
35,9 \\
12,6 \\
13,2 \\
15,8 \\
11,7\end{array}$ & $\begin{array}{l}1,6 \\
5,6 \\
1,9 \\
2,0 \\
2,4 \\
1,8\end{array}$ \\
\hline Итого & 100,0 & 15,3 & Итого & 100,0 & 15,3 \\
\hline
\end{tabular}

K сожалению, осталось невыясненным, какие именно соединения обусловливают столь большие потери, наблюдаемые при хроматографическом разделении несульфированной части кислотного слоя. Во всяком случае, потери хроматографического разделения следует отнести за счет соединений, образующихся в результате протекания вторичных, так называемых паразитических реакций.

Из данных табл. 3 следует, что общая глубина превращения олефинов фракции $250-350^{\circ}$ в присутствии концентрированной серной кислоты составляет около $87 \%$, причем полезная глубина его не превышает $47 \%$.

Количество остаточных олефинов составляет $13 \%$, и около $40 \%$ олефиновых углеводородов вовлекается в паразитические реакции полиме- 
을

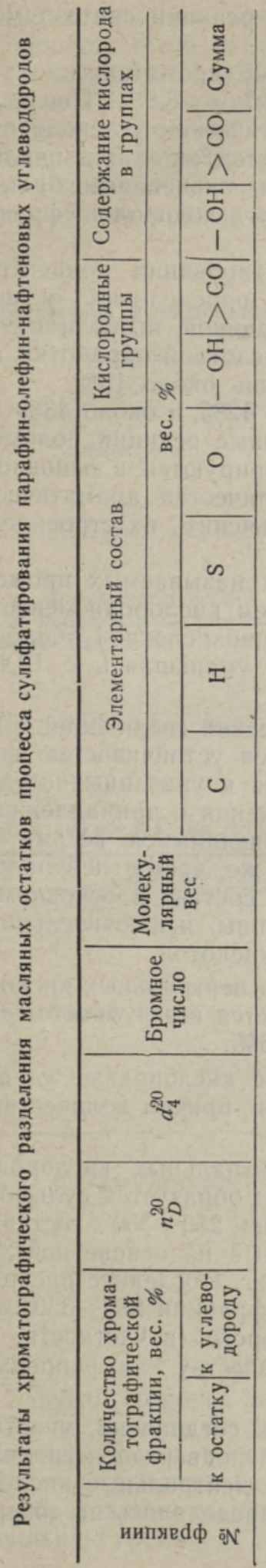

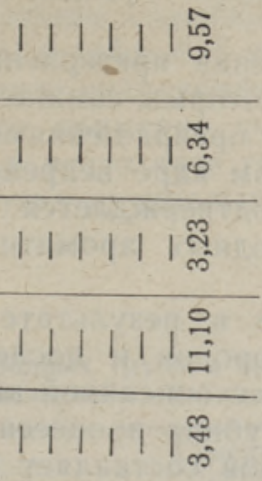

0.00000
000000

0.000000

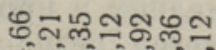

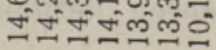

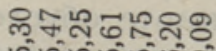

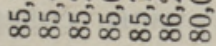

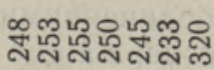

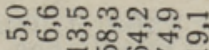

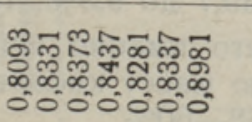

으잉ㅇㅇ요요

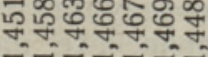

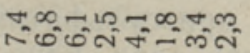

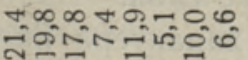

-Nm+non 产

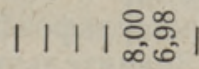

| | | | लूస్ |

| | | | 요요 |

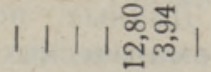

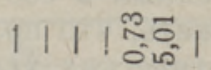

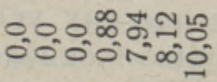

은균ํํำ

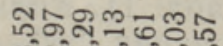

จงละシニニ

สెผ ธ็ํำผ

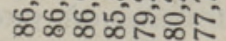

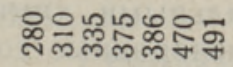

으묘

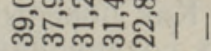

눙ำㄱํㅇำ

\%क\&ष

우슈유잉요으

난

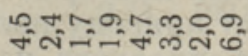

๑0

-Nmtincor 竎 
ризации и окисления, сопутствующие основной реакции синтеза моноалкилсульфоэфиров.

Значительные изменения претерпевают также ароматические углеводороды, количество которых снижается с 28,7 до $8,8 \%$. Последнее, по-видимому, связано с превращениями ароматических углеводородов, имеющих при бензольном ядре непредельные алкильные или циклические структуры, что подтверждается высокими значениями бромных чисел (около 64) исходных ароматических углеводородов фракции $250-350^{\circ}\left[{ }^{11}\right]$

Данные, полученные в результате сульфатирования концентрата ароматических углеводородов и последующих определений, осуществленных в соответствии с описанной выше методикой, позволили установить, что полезная глубина процесса сернокислотной обработки ароматических углеводородов составляет всего лишь около $15 \%$.

Количество остаточных углеводородов равно $42 \%$, и около $43 \%$ ароматических углеводородов вовлекается в побочные реакции полимеризации и окисления, продукты которых концентрируются в основном в кислотном слое. Участие такого большого количества ароматических углеводородов в побочных реакциях можно объяснить их строением, о котором упоминалось выше.

Обращает на себя внимание поведение так называемых промежуточных ароматических соединений с содержанием кислорода менее $5 \%$ (табл. 1). Количество последних в процессе сернокислотной обработки фракции $250-350^{\circ}$ изменяется незначительно, уменьшаясь с 12,4 до $9,2 \%$.

Такая инертность промежуточных ароматических соединений к концентрированной серной кислоте обусловливается устойчивостью функциональной кислородной группы, содержащейся в указанных соединениях. Последнее дает основание для предположения о принадлежности указанных соединений к простым эфирам, являющимися весьма стабильными химическими соединениями. В то же время нейтральные кислородные соединения, содержащие в своем составе в основном гидроксильные и карбонильные кислородные группы, исключительно активно реагируют с концентрированной серной кислотой.

Как показывают данные табл. 1, содержание нейтральных кислородных соединений во фракции $250-350^{\circ}$ уменьшается в результате сернокислотной обработки с 39,7 до $9,5 \%$, т. е. на $76 \%$.

Было установлено, что именно нейтральные кислородные соединения составляют основную массу кислотного слоя, причем количество их в последнем достигает $58-60 \%$.

Данные сульфатирования концентрата нейтральных кислородных соединений показали, что в результате процесса образуется сульфопродукт, выход которого в пересчете на фракцию $250-350^{\circ}$ составляет около $5 \%$. При этом сульфопродукт, получаемый на основе нейтральных кислородных соединений, имеет темный цвет. Последнее раскрывает природу получаемого при сульфатировании фракции $250-350^{\circ}$ сульфопродукта из кислотного слоя, качество которого (в частности, цвет продукта) в значительной степени уступает качеству сульфопродукта, выделенного из масляного слоя.

С целью выяснения характера кислородных соединений, участвующих в образовании сульфопродукта, последний подвергался гидролизу в кислой среде. Продукты гидролиза, а также нейтральные кислородные соединения до и после сульфатирования определялись на содержание гидроксильной и карбонильной групп. 
Кроме того, на основании данных элементарного анализа указанных веществ было установлено общее содержание кислорода. Результаты этих определений приведены в табл. 4,5 и 6.

Из табл. 4 видно, что содержание гидроксильной группы в продуктах гидролиза составляет $4,53 \%$, что примерно соответствует количеству высших спиртов, образуюшихся в результате гидролиза сульфопродукта, полученного и на основе других групповых компонентов углеводородного характера.

Таблица 4

Содержание функциональных кислородных групп в продуктах сульфатирования нейтральных кислородных соединений

\begin{tabular}{|c|c|c|c|c|c|c|}
\hline \multirow[b]{3}{*}{ Соединение } & \multicolumn{6}{|c|}{ Содержание, вес. \% } \\
\hline & \multicolumn{2}{|c|}{ кислородных групп } & \multicolumn{4}{|c|}{ кислорода } \\
\hline & $-\mathrm{OH}$ & $>\mathrm{CO}$ & $-\mathrm{OH}$ & $>\mathrm{CO}$ & сумма & $\begin{array}{c}\text { данные эле- } \\
\text { ментарного } \\
\text { анализа }\end{array}$ \\
\hline $\begin{array}{l}\text { Н. к. с. до сульфатирования } \\
\text { Н. к. с. после сульфатирования } \\
\text { Продукты гидролиза }\end{array}$ & $\begin{array}{l}2,33 \\
2,08 \\
4,53\end{array}$ & $\begin{array}{r}10,50 \\
9,68 \\
4,40\end{array}$ & $\begin{array}{l}2,19 \\
1,96 \\
4,26\end{array}$ & $\begin{array}{l}6,00 \\
5,52 \\
2,60\end{array}$ & $\begin{array}{l}8,19 \\
7,48 \\
6,86\end{array}$ & $\begin{array}{r}8,34 \\
7,99 \\
12,04\end{array}$ \\
\hline
\end{tabular}

Примеч ан и е. Здесь и далее н. к. с. - нейтральные кислородные соединения.

Таблица 5

Баланс распределения гидроксильных групп в продуктах сульфатирования н. к. с.

\begin{tabular}{|c|c|c|c|c|c|}
\hline \multicolumn{3}{|l|}{$\mathrm{Pacxoд}$} & \multicolumn{3}{|l|}{ Приход } \\
\hline \multirow[b]{2}{*}{ Исходное сырье } & \multicolumn{2}{|c|}{$\begin{array}{c}\text { Содержание } \\
\text { - ОН-групп, } \\
\text { вес. } \%\end{array}$} & \multirow[b]{2}{*}{ Продукты сульфатирования } & \multicolumn{2}{|c|}{$\begin{array}{l}\text { Содержание } \\
\text { - ОН-групп, } \\
\text { вес. } \%\end{array}$} \\
\hline & 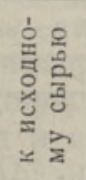 & 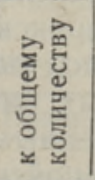 & & 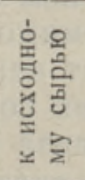 & 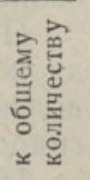 \\
\hline Н. к. с. до сульфатирования & 2,33 & 100,0 & $\begin{array}{l}\text { Остаточные н. к. с. (после } \\
\text { сульфатирования) } \\
\text { Продукты гидролиза } \\
\text { Разность }\end{array}$ & $\begin{array}{l}1,82 \\
0,41 \\
0,10\end{array}$ & $\begin{array}{r}78,2 \\
17,6 \\
4,2\end{array}$ \\
\hline Итого & 2,33 & 100,0 & И т o ro & 2,33 & 100,0 \\
\hline
\end{tabular}

С другой стороны, данные балансовых расчетов общего содержания кислорода в продуктах сульфатирования нейтральных кислородных соединений (табл. 6) свидетельствуют об отсутствии какого-либо увеличения количества кислорода, которое можно было бы отнести за счет образования высших спиртов из соединений, не содержащих гидроксильную группу. 
Как видно из приведенных в табл. 5 данных о распределении гидроксильных групп, суммарное количество гидроксила в продуктах сульфатирования соответствует его первоначальному содержанию в исходных нейтральных кислородных соединениях.

таблича 6

Баланс распределения общего кислорода (данные элементарного анализа) в продуктах сульфатирования н. к. с.

\begin{tabular}{|c|c|c|c|c|c|}
\hline \multicolumn{3}{|l|}{$\mathrm{Pacxoд}$} & \multicolumn{3}{|l|}{ Приход } \\
\hline \multirow[b]{2}{*}{ Исходное сырье } & \multicolumn{2}{|c|}{$\begin{array}{c}\text { Содержание } \\
\text { кислорода, } \\
\text { вес. } \%\end{array}$} & \multirow[b]{2}{*}{ Продукты сульфатирования } & \multicolumn{2}{|c|}{$\begin{array}{c}\text { Содержание } \\
\text { кислорода, } \\
\text { вес. \% }\end{array}$} \\
\hline & 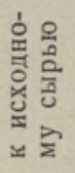 & 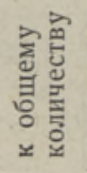 & & 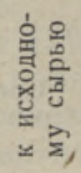 & 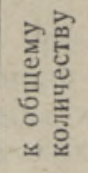 \\
\hline Н. к. с. до сульфатирования & 8,34 & 100,0 & $\begin{array}{l}\text { Остаточные н. к. с. (после } \\
\text { сульфатирования) } \\
\text { Продукты гидролиза } \\
\text { Разность }\end{array}$ & $\begin{array}{l}6,99 \\
1,08 \\
0,27\end{array}$ & $\begin{array}{r}83,8 \\
13,0 \\
3,2\end{array}$ \\
\hline Ит о го & 8,34 & 100,0 & Итого & 8,34 & 100,0 \\
\hline
\end{tabular}

Таким образом, приведенные выше данные позволяют заключить, что образующиеся в результате сульфатирования нейтральных кислородных соединений сульфоэфиры являются продуктами присоединения серной кислоты к гидроксильной группе, содержащейся в исходном сырье. Это свидетельствует о наличии в сланцевой смоле кислородных соединений, содержащих гидроксильную группу, благодаря присутствию которой эти соединения обладают в данных условиях характерным для спиртов свойством образовывать с серной кислотой сложные эфиры.

Помимо такого «спиртового» гидроксила, указанные соединения содержат карбонильную группу, что подтверждается результатами определения содержания функциональных кислородных групп в продуктах гидролиза сульфоэфиров, представленными в табл. 4.

Из сказанного следует, что с серной кислотой реагируют все основные групповые компоненты фракции 250-350 (олефиновые, ароматические углеводороды и нейтральные кислородные соединения), причем целевые продукты реакции представляют собой сложные моноэфиры серной кислоты. Преобладают при этом моноалкилсульфаты, полученные на базе олефиновых углеводородов, количество которых составляет $53 \%$ от суммарного выхода активного вещества сульфопродукта.

Данные табл. 7 показывают, что молекулярный вес активного вещества сульфопродукта, выделенного из кислотного слоя, как правило, выше молекулярного веса соответствующих продуктов, полученных из масляного слоя, молекулярный вес гидрофобной части которых соответствует среднему молекулярному весу исходного сырья. Это свидетельствует о возможности вторичного взаимодействия продуктов полимеризации, а вероятнее всего димеризации олефинов с серной кислотой, в результате чего образуются алкилсульфоэфиры с более высоким молекулярным весом. 
Сравнивая выходы сульфопродукта, получаемого в результате сульфоэтерификации различных групповых компонентов смолы, можно заключить, что распределение последнего в масляном и кислотном слоях зависит как от количества применяемой в процессе серной кислоты (ее количественной способности растворять алкилсульфоэфиры), так и от ирисутствия в смоле групповых компонентов (например ароматических углеводородов), способных растворять соответствующие алкилсульфопроизводные в масляном слое.

Таблища 7

Характеристика активного вещества сульфопродукта, полученного из фракции $250-350^{\circ}$

\begin{tabular}{|c|c|c|c|c|}
\hline \multirow{2}{*}{ Исходное сырье } & \multirow{2}{*}{$\begin{array}{c}\text { Вид сульфо- } \\
\text { продукта }\end{array}$} & \multirow{2}{*}{$\begin{array}{l}\text { Выход актив- } \\
\text { ного вещест- } \\
\text { ва на фрак- } \\
\text { цию, вес. \% }\end{array}$} & \multicolumn{2}{|c|}{$\begin{array}{c}\text { Средний молекулярный } \\
\text { вес }\end{array}$} \\
\hline & & & $\begin{array}{c}\text { активного } \\
\text { вешества }\end{array}$ & $\begin{array}{l}\text { продуктов } \\
\text { гидролиза }\end{array}$ \\
\hline $\begin{array}{l}\text { Суммарная фракция } \\
250 \div 350^{\circ}\end{array}$ & $\begin{array}{c}\mathrm{M} \\
\mathrm{K}\end{array}$ & $\begin{array}{r}5,6 \\
14,0\end{array}$ & $\begin{array}{l}335,9 \\
405,0\end{array}$ & $\begin{array}{l}244,1 \\
301,0\end{array}$ \\
\hline $\begin{array}{l}\text { Парафин-олефин- } \\
\text { нафтеновые углево- } \\
\text { дороды } \\
\text { Ароматические угле- } \\
\text { водороды }\end{array}$ & $\begin{array}{l}\mathrm{M} \\
\mathrm{K} \\
\mathrm{M} \\
\mathrm{K}\end{array}$ & $\begin{array}{l}2,5 \\
7,8 \\
3,4 \\
2,9\end{array}$ & $\begin{array}{l}351,7 \\
408,8 \\
338,1 \\
382,1\end{array}$ & $\begin{array}{l}250,3 \\
305,4 \\
231,9 \\
289,9\end{array}$ \\
\hline $\begin{array}{l}\text { Нейтральные кисло- } \\
\text { родные соединения }\end{array}$ & K & 5,0 & 381,5 & 280,2 \\
\hline
\end{tabular}

Пр и ме чан ие. Здесь и далее $M$ - сульфопродукт, выделенный из масляного слоя, К - сульфопродукт, выделенный из кислотного слоя.

Результаты исследования позволяют утверждать, что сульфопродукт, получаемый на основе фракции $250-350^{\circ}$, относится к категории натриевых солей моносульфоэфиров - сульфопроизводных различных

\section{Таблаца 8}

Поверхностное натяжение сульфопродукта, полученного на основе некоторых групповых компонентов сланцевой смолы

\begin{tabular}{|c|c|c|c|c|c|}
\hline \multirow{3}{*}{$\begin{array}{l}\text { Концентрация } \\
\text { активного ве- } \\
\text { щества в рас- } \\
\text { творе, вес. \% }\end{array}$} & \multicolumn{5}{|c|}{ Поверхностное натяжение, дина/см } \\
\hline & \multicolumn{2}{|c|}{$\begin{array}{c}\text { олефиновые } \\
\text { углеводоро- } \\
\text { ды }\end{array}$} & \multicolumn{2}{|c|}{$\begin{array}{c}\text { ароматиче- } \\
\text { ские углево- } \\
\text { дороды }\end{array}$} & \multirow{2}{*}{$\begin{array}{c}\begin{array}{c}\text { нейтральные } \\
\text { кислородные } \\
\text { соединения }\end{array} \\
\text { K }\end{array}$} \\
\hline & M & K & M & K & \\
\hline 1,00 & 32,2 & 33,6 & 38,4 & 40,0 & 44,0 \\
\hline 0,50 & 33,6 & 37,8 & 42,9 & 45,0 & 56,0 \\
\hline 0,25 & 47,7 & 43,4 & 47,8 & 51,8 & 58,0 \\
\hline 0,125 & 52,0 & 56,0 & 52,4 & 54,6 & 67,2 \\
\hline $\begin{array}{l}0,063 \\
0\end{array}$ & 58,1 & 61,6 & $\begin{array}{l}63,1 \\
72,8\end{array}$ & 64,0 & 68,6 \\
\hline
\end{tabular}

групповых компонентов: олефиновых и ароматических углеводородов и нейтральных кислородных соединений. Отсюда становится понятным, что показатели поверхностно-активных свойств такого сульфопродукта являются величинами аддитивными. 
Как это следует из табл. 8, где приведены результаты определения поверхностного натяжения водных растворов сульфопродукта различной концентрации $\left[{ }^{10}\right]$, поверхностно-активные свойства последнего зависят от характера их гидрофобной части, быстро ухудшаясь с переходом от олефиновых к ароматическим и далее к нейтральным кислородным соединениям.

\section{О составе активного вещества сульфопродукта}

Результаты анализа состава активного вещества сульфопродукта, получаемого путем сернокислотной обработки фракции $250-350^{\circ}$, показали, что активное вещество в данном случае представлено в основном сложноэфирной группировкой.

В табл. 9 приведены данные анализа активного вещества сульфопродукта, полученного в результате сернокислотной обработки фракции $200-300^{\circ}$, а также фракций, кипящих в пределах $200-250$ и $125-300^{\circ}$. Эти данные показывают, что активное вещество содержит, наряду с сульфоэфирами, соединения, которые не разлагаются в кислотной среде и не образуют высших спиртов. Такие соединения относятся к классу алкилароматических сульфокислот.

Таблица 9

Характеристика состава активного вещества сульфопродукта

\begin{tabular}{|c|c|c|c|c|c|c|c|c|}
\hline \multirow{2}{*}{ 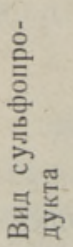 } & \multirow{2}{*}{ 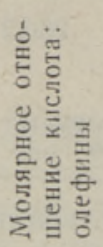 } & \multirow{2}{*}{ 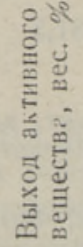 } & \multicolumn{4}{|c|}{ Средний молекулярный вес } & \multicolumn{2}{|c|}{$\begin{array}{l}\text { Содержание в актив- } \\
\text { ном вешестве, вес. \% }\end{array}$} \\
\hline & & & 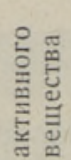 & 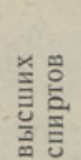 & 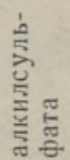 & 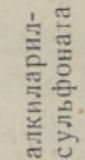 & 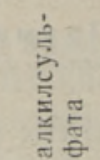 & 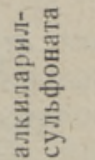 \\
\hline
\end{tabular}

Фракция $200 \div 300^{\circ}$ (средний молекулярный вес 164)

\begin{tabular}{l|r|r|l|l|l|l|l|l}
$M$ & $1,5: 1$ & 9,7 & 353,2 & 235 & 338 & 442 & 85,4 & 14,6 \\
$\mathrm{~K}$ & 13,5 & 361,5 & 252 & 355 & 417 & 89,7 & 10,3
\end{tabular}

Фракция $200 \div 250^{\circ}$ (средний молекулярный вес 142)

\begin{tabular}{l|l|l|l|l|l|l|l|l}
$M$ & $1: 1$ & 13,4 & 377,4 & 207 & 310 & 495 & 63,4 & 36,6 \\
$\mathrm{~K}$ & $1: 1$ & 14,1 & 381,7 & 246 & 350 & 450 & 69,0 & 31,0
\end{tabular}

Фракция $125 \div 300^{\circ}$ (средний молекулярный вес 147)

\begin{tabular}{l|r|l|l|l|l|l|l|l} 
Слои не & $1: 1$ & 32,3 & 317,5 & 199 & 302 & 387 & 81,3 & 18,7 \\
разде- & $1,5: 1$ & 30,1 & 323 & 204 & 307 & 394 & 82,0 & 18,0 \\
лялись & & & & &
\end{tabular}

Из представленных в табл. 9 данных видно, что алкилароматические сульфокислоты, полученные на основе фракции $200-250^{\circ}$, имеют молекулярный вес порядка $450-495$. Это намного выше предполагаемого молекулярного веса сульфокислот, образующихся в результате присоединения группы $\mathrm{SO}_{3} \mathrm{Na}$ к ароматическому углеводороду со средним молекулярным весом 142. Аналогичные результаты получаются и в слу- 
чае определения молекулярного веса алкилсульфоэфиров и продуктов их гидролиза. Следовательно, можно предположить, что в данном случае происходит процесс димеризации низкомолекулярных олефинов, продукты которого (димеры) образуют моноалкилсульфоэфиры.

Однако процесс сульфоэтерификации связан не только с образованием димеров, но и с реакцией алкилирования малозамещенных ароматических углеводородов с последующим сульфированием в ядро образующихся алкилароматических углеводородов. При этом с понижением границ кипения исходного сырья количество сульфированных (а также и алкилированных) ароматических углеводородов увеличивается. Кроме того, суммарный выход сульфопродукта увеличивается до $30-32 \%$, в то время как в случае сульфоэтерификации фракции $250-350^{\circ}$ он не превышал $20 \%$.

Все это позволяет значительно увеличить сырьевые ресурсы получения качественных синтетических моющих веществ, соответствующих требованиям, предъявленным к водорастворимым поверхностно-активным веществам. В работе [13] было показано, что сланцевый сульфопродукт по своим поверхностно-активным свойствам не уступает французскому препарату, получаемому из прямоцепочных $\alpha$-олефинов. Это, повидимому, объясняется тем, что сульфопродукт, получаемый из средних фракций сланцевой смолы, состоит из смеси алкилсульфата и алкиларилсульфоната.

Как известно, смеси подобного рода обладают лучшими поверхностно-активными свойствами, чем каждая составляющая в отдельности $\left.{ }^{14}\right]$. Последнее, очевидно, и является причиной удовлетворительных свойств сланцевого сульфопродукта, несмотря на то, что исходным сырьем для его получения служат олефины далеко не идеального строения.

\section{Выводы}

1. Разработана методика изучения химизма процесса сульфатирования сланцевой смолы, заключающаяся в хроматографическом разделении смолы на отдельные групповые компоненты с последующей сернокислотной обработкой и анализом получающихся продуктов. Это позволило, наряду с природой получаемых поверхностно-активных веществ, определить не только состав остаточной фракции, но и установить характер и природу большинства соединений, присутствующих в кислотном слое.

2. Показано, что большое влияние на характер процесса сульфатирования олефинов оказывают химичесқий состав и строение отдельных компонентов смолы, изменяющиеся с температурой кипения последней. Так, если при сернокислотной обработке фракции $250-350^{\circ}$ в основном доминирует реакция сульфоэтерификации, то при использовании более низкокипящих фракций известное значение начинает приобретать реакция алкилирования ароматических углеводородов с последующим сульфированием в ароматическое ядро.

3. Помимо олефиновых углеводородов сланцевой смолы в реакции с концентрированной серной кислотой принимают участие ароматические углеводороды и нейтральные кислородные соединения.

4. Наряду с продуктами глубокого превращения, часть нейтральных кислородных соединений образует сульфоэфиры, представляющие собой продукты присоединения серной кислоты к гидроксильной группе кислородных соединений. 
5. Сульфопродукт, -полученный на базе нейтральных кислородных соединений, имеет темный цвет и его водные растворы обладают низкими поверхностно-активными свойствами.

6. Необходимым условием получения высококачественного сульфопродукта является предварительное удаление из исходного сырья кислородных соединений, содержащих гидроксильную группу.

7. Удовлетворительные поверхностно-активные свойства сланцевого сульфопродукта, полученного на базе рафинированных фракций $200-300$ или $125-300^{\circ}$, объясняются химическим составом получаемого активного вещества, которое состоит из смеси алкилсульфатов и алкиларилсульфонатов.

\title{
Л ИТЕРАТУ РА
}

1. B. I. M a i r, A. F. For z i at i, J. Res. Nat. Bür. Standards, 34, 1945, p. 435.

2. W. E. C a d y, H. S. Se eli ng, Ind. Eng. Chem., 44, 1952, p. 2636.

3. Н. С. Богусл авская, А. С. Великов к и й, Нефт. х-во, № 3,1947, стр. 52.

4. N y u | u. Wá móś, Chem. Technik, H. 2, 1957, S. 72.

5. H. D. D u b o is, D. A. Skoog, Anal. Chem., 20, 1948, p. 624.

6. De Walt, R. Gle n n, Anal. Chem., 24, 1952, p. 1789.

7. A. T. Feuell, J. H. Skello n, Analyst, 78, 1953, p. 135-140.

8. Merron, Shifferly, Ind. Eng. Chem., An. Ed., 18, 1949, p. 49.

9. Единые методы анализа и оценки моющих средств, Л., ВНИИЖ, 1958, стр. 28-30.

10. Единые методы анализа и оценки моющих средств, Л., ВНИИЖ, 1958, стр. 49.

11. И. Б. Кудря вце в, Исследование обесфеноленной фракции $250-350^{\circ}$ сланцевой смолы установки с твердым теплоносителем комбината «Кивиыли», Сб. Горючие сланцы. Химия и технология, вып. 3, Таллин, 1960.

12. А. Т. К ылль, В. А. Р иккен, И. Б. Ку др явцев, Возможности. производства синтетических моющих веществ из олефиновых углеводородов сланцевой смолы. Технич. информ. Гос. научно-техн. ком-та при СМ ЭССР, № 11, Таллин, 1958.

13. А. Т. Кыл ль, И. Б. К удря вц ев, В. А. Р и к кен, О сульфатировании олефиновых углеводородов сланцевой смолы, Изв. АН ЭССР. Сер. техн. и физ.-мат. наук, т. VII, № 2, 1958, стр. 115.

14. St. Anastasiu, E. I elescu, S. Holeman, R. A isman, Rev. Chim. (Romîn.), 8, 1957, p. 509.

\author{
Инотитут химии \\ Академии наук Эстонской ССР \\ Поступила в редакцию \\ 18. III 1960
}

\section{ALKUOLSULFAATIDE SUNTEESIPROTSESSI KEMISMI UURIMINE POLLEVKIVITORVA OLEFIINIDE BAASIL}

\author{
I. Kudrjavtsev, \\ tehnikakandidaat
}

\section{Resümee}

Käesoleva artikli autor uuris pōlevkiviōli neutraalse osa töötlemist väävelhappega. Töö peamiseks eesmärgiks oli leida viis, kuidas ōlis leiduvaid olefiinseid süsivesinikke täielikult kasutada nende üleviimise teel pindaktiivsete omadustega monoalküülsulfaatideks.

Uuriti detailselt üksikute ōlis leiduvate olefiinsete süsivesinike rühmade komponente, eraldades neid õlist kromatograafilisel teel. Pōlevkivōli baasil valmistatud sulfoprodukt koosneb olefiinsete, aromaatsete ja neutraalsete hapnikuühendite komponentidest. Sellest tingituna sōltuvad sulfoprodukti pindaktiivsed ja muud omadused (näit. värvus, lōhn) nimetatud ühendite hulgast; kōige halvemate omadustega on neutraalsete hapnikuühen- 
dite baasil valmistatud sulfoprodukt, mis on tekkinud väävelhappe liitumisel hapnikuühendite hüdroksüülrühmaga, kusjuures tema struktuuris esineb ühtlasi karbonüülne rühm. Järelikult on kõrge kvaliteediga sulfoprodukti saamise eelduseks hüdroksüülse rühmaga hapnikuühendite eelnev kõrvaldamine lähteainest.

Rahuldavate pindaktiivsete omadustega sulfoprodukti saab pōlevkiviōli rafineeritud fraktsioonist $200-300^{\circ}$ vōi $125-300^{\circ}$ sel juhul, kui sulfoprodukt on alküülsulfaadi $(84 \%)$ ja alküülarüülsulfonaadi $(16 \%)$ segu. Sellise segu kui terviku pindaktiivsed omadused on paremad kui tema üksikutel koostisosadel.

Eesti NSV Teaduste Akadeemia Keemia Instituut
Saabus toimetusse

18. III 1960

\section{RESEARCHES INTO THE CHEMISM OF THE SYNTHESIS OF ALKYLSULFATES ON THE BASE OF OIL SHALE TAR OLEFINS}

\section{Kudryavtsev}

\section{Summary}

The present paper deals with the processing with sulfuric acid of the neutral part of oil shale tar, directed mainly towards a rational utilization of olefinic carbohydrates contained in the tar (a synthesis of surface-active monoalkylsulfates).

A detailed study of the process was made with individual group-components separated with the help of chromatography. The active substance of the sulfoproduct obtained on the base of oil shale tar consists of olefins, aromatic hydrocarbons and neutral oxygen compounds. Therefore the surface-active and other qualities (colour, smell) of the sulfoproduct of oil shale tar depend on the corresponding properties of separate components of the active substance. From that point of view, the least desirable component is the sulfoproduct obtained from neutral oxygen compounds. The latter are represented by the product of sulfuric acid combined with the hydroxyl group of oxygen compounds having, in addition, a carbonyl group. Therefore, a necessary condition for obtaining a sulfoproduct of a high quality is the preliminary elimination from the raw product of oxygen compounds having a hydroxyl group.

The satisfactory surface-active properties of the sulfoproduct obtained on the base of the refined fractions of $200^{\circ}-300^{\circ}$, or $125^{\circ}-300^{\circ} \mathrm{C}$, may be explained by the chemical composition of the active substance composed of a mixture of alkylsulfate (84\%) and alkylarylsulfonate $(16 \%)$. Mixtures of similar kind possess better surface-active properties than each component taken separately.

Academy of Sciences of the Estonian S.S.R., Institute of Chemistry

Received

March 18th, 1960 